\title{
Effect of Anatomical and Physiological Factors on Ultrasonic Breast Imaging Reporting and Data System Score in Iraqi Women Presenting with Breast Lumps
}

\author{
Ahmed Fakhir Hameed*(iD, Sameh S. Akkila (D), Khalida I. Noel(D, Saad Alshahwani(D) \\ Department of Human Anatomy, Mustansiriyah University, College of Medicine, Baghdad, Iraq
}

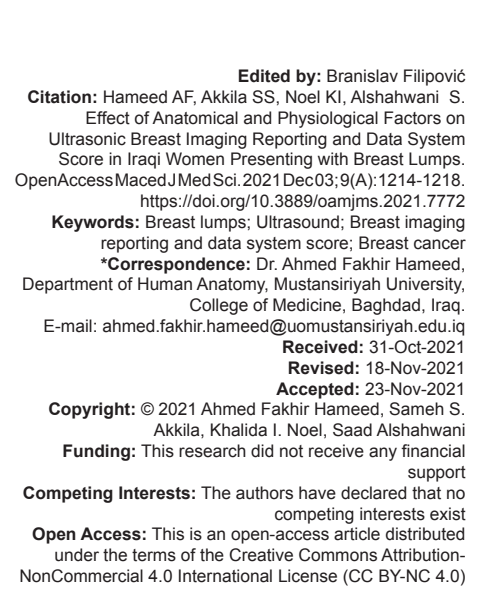

Introduction

Globally, breast cancer is the most known malignant disease in women over the age of 40 in the world, and the most stated cause of tumor death in ladies [1], [2]. It has been noticed that the fast recognition and early screening followed by suitable management declining the related morbidity and mortality degrees of the disease [3]. Earlier surveys from Iraq have stated that breast cancer is the most common recorded malignancy [4] and that most of the disease cases are often spotted among middle-aged ladies in moderately advanced stages [5], [6], [7]. Presenting with a breast lump is a common complaint in the female population. Although benign lesions form the majority of breast lumps, breast cancer remains a common hazard for women of different ages [8]. Radiological assessment of lumps offer a cost-effective non-invasive tool for diagnostic and therapeutic purposes [9].

Here, we assess the effects of anatomical and physiological factors on the results of the radiological assessment of breast lumps using ultrasound breast imaging reporting and data system (BI-RADS) scoring.

\section{Methods}

\section{Study deign and setting}

A total of 60 women were enrolled in the study, they were randomly selected after their consent at the Clinic for Early Detection of Breast Cancer atAl-Yarmouk Teaching Hospital, Baghdad and Al-Shahwany private ultrasound clinic in Baghdad during a 2 month period (November-December 2019).

\section{Eligibility}

Inclusion criteria was any female presenting with a breast lump for Ultrasound assessment. Exclusion criteria comprised a history of breast augmentation or signs and symptoms of breast inflammatory disorders.

\section{Procedure}

Anthropometric breast size measurement was adapted after Kayar et al. [10]. A specialized nurse used tape measure and simple ruler to take the measurements. 
Each of the three radiuses (latera [LR], medial [MR], inferior $[\mathrm{IR}])$ was measured from the center of the nipple to the skin fold of the breast with the chest wall in that direction. Mammary projection (MP) was measured using a simple ruler from the chest wall to the apex of the breast. All measurements were recorded in centimeters $(\mathrm{cm})$ and the breast volume was calculated according to the equation:

$$
\begin{aligned}
& \text { Breast size }\left(\mathrm{cm}^{3}\right)=\pi / 3 \times M P 2 \times \\
& (M R+L R+I R-M P)[10]
\end{aligned}
$$

\section{Ultrasonography}

Breast ultrasound was performed by a specialist using Voluson10@ Ultrasound Machine (USA) with highfrequency rate linear probe at 8-12 $\mathrm{MHz}$. Ultrasound results were expressed according to the ultrasound BI-RADS score, taking into consideration different mass criteria such as shape, orientation, margin, echo pattern, vascularity, calcification, and posterior features (Figure 1). Simply put, lower scores $(\leq 3)$ indicate benign or normal findings. Scores of 4 or 5 have increased probability of malignancy meriting a biopsy [11].

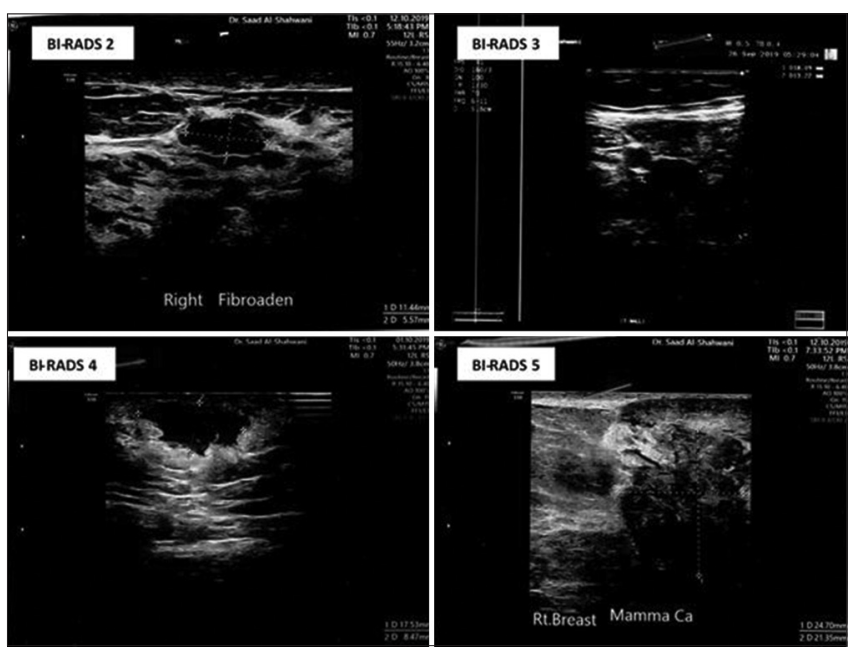

Figure 1: Different ultrasound breast imaging reporting and data system scores recorded in Iraqi women presenting with breast lumps

\section{Data sources}

Aquestionnaire was completed as shown below regarding the patient's age, marital status, menopausal status, parity, history of breastfeeding, breast disease (personal and familial), and affected breast quadrant.

\section{Statistical analysis}

Data were plotted and analyzed using Statistical Package for the Social Sciences version 24 and Microsoft office excel 2016. Statistical significance was calculated at a confidence interval of $95 \%$ with a $p<0.05$ being of statistical significance. Numerical data were presented as means \pm standard deviation (SD) for hypothesis testing (t-test) while categorical data were presented as

\begin{tabular}{|c|c|}
\hline Case number / Name & \\
\hline \multicolumn{2}{|l|}{ Age (Years) } \\
\hline \multicolumn{2}{|l|}{ Age of menarche } \\
\hline Menopausal status & $\square$ 1. Premenopausal $\quad \square$ 2. Postmenopausal \\
\hline \multirow{4}{*}{$\begin{array}{l}\text { Quadrant of breast lump (If lump involves } \\
\text { more than } 1 \text { quadrant, consider the quadrant } \\
\text { that has the greatest mass) }\end{array}$} & $\square$ 1. Upper lateral \\
\hline & $\square$ 2. Lower lateral \\
\hline & $\square$ 3. Lower medial \\
\hline & $\square$ 4. Upper medial \\
\hline Personal history of breast disease & $\square$ 1. Yes $\square$ 2. No \\
\hline Family history of breast disease & $\square$ 1. Yes $\square$ 2. No \\
\hline Marital status & $\square$ 1. Single $\square$ 2. Married \\
\hline \multicolumn{2}{|l|}{ Parity (Number of children) } \\
\hline Breast feeding & $\square$ 1. Yes \\
\hline \multicolumn{2}{|l|}{ Breast feeding duration (months) } \\
\hline Lymph node enlargement & $\square$ 3. Unknown \\
\hline \multirow{4}{*}{$\begin{array}{l}\text { Anatomic (anthropometric) breast } \\
\text { measurement (cm) (The measurements } \\
\text { should be performed when the patient is } \\
\text { sitting or standing with her arms at her sides) } \\
\text { see images below) }\end{array}$} & Mammary projection (MP): \\
\hline & Medial radius (MR): \\
\hline & Lateral radius (LR): \\
\hline & Inferior radius (IR): \\
\hline Lump echogenicity (Ulrasound) & $\square$ 1. Solid $\quad \square$ 2. Fluid-filled \\
\hline Lump follow-up diagnosis (if present) & $\square$ 1. Benign $\square$ 2. Malignant $\square$ 3. Unknown \\
\hline
\end{tabular}
frequency and percentage for Chi-square testing.

\section{Results}

The mean age of females was $41.42 \pm$ 12.5 years, ranged from 21 to 70 years. Table 1 summarizes the descriptive frequencies of the patients data. Most cases (46.7\%) scored BI-RADS II, followed by scores of III $(21.6 \%)$, IV $(16.7 \%)$, and V (15\%), as shown in Figure 2. Breast size showed a positive correlation with the BI-RADS score, which one? $(r=0.348$ at $p=0.046)$, i.e. the greater the breast size the greater the BI-RAD score was.

Table 1: Anatomical and physiological features of Iraqi women presenting with a breast lump

\begin{tabular}{ll}
\hline Criteria & $\%$ (No.) No. 0 (count) \\
\hline Menopausal status & $76.7(46)$ \\
Premenopausal & $23.3(14)$ \\
Postmenopausal & \\
Marital status & $86.7(52)$ \\
$\quad$ Married & $13.3(8)$ \\
Single & \\
Parity (in married women) & $7.7(4)$ \\
$\quad$ Nulliparous & $5.8(3)$ \\
Uniparous & $86.5(45)$ \\
Multiparous & \\
Personal history of breast disease & $25(15)$ \\
Yes & $75(45)$ \\
No & \\
Family history of breast disease & $50(30)$ \\
Yes & $50(30)$ \\
No & \\
Breast feeding history (for parous women) & $91.7 \%(44)$ \\
Yes & $8.3(4)$ \\
No & \\
Affected breast quadrant & $41.7(25)$ \\
Upper lateral & $35(21)$ \\
Lower lateral & $11.7(7)$ \\
Lower medial & $11.7(7)$ \\
Upper medial & \\
Lymphadenopathy & $43.3(26)$ \\
Yes & $56.7(34)$ \\
No & \\
\hline
\end{tabular}




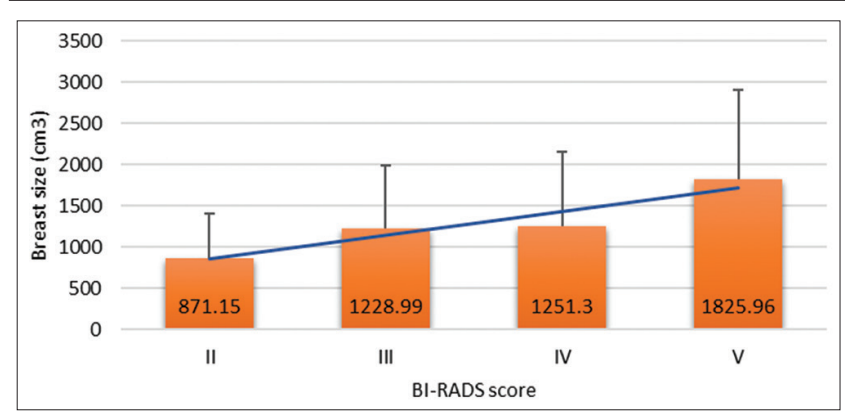

Figure 2: Effect of breast size on breast imaging reporting and data system score in Iraqi women with breast lumps (Numbers represent means, error bars $=+S D$, trend line = linear correlation)

Increasing age was also associated with increased BI-RADS scores $(r=0.649)$ with high statistical significance $(p=0.000)$ as shown in Figure 3 .

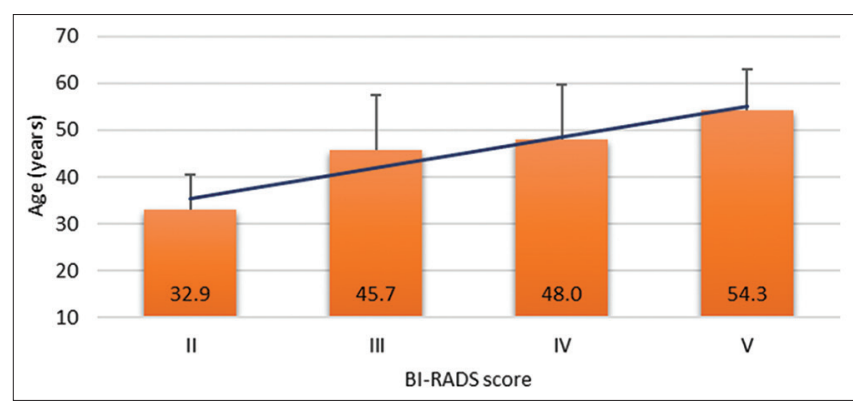

Figure 3: Effect of age on breast imaging reporting and data system score in Iraqi women with breast lumps (Numbers represent means, error bars $=+S D$, trend line $=$ linear correlation)

Postmenopausal women had significantly higher BI-RADS scores $(p=0.004)$. Patients with personal or family history of breast disease had also higher scores ( $p=0.001)$. Marital status, parity, breastfeeding history, and anatomical quadrant of the lump did not affect the BI-RADS score significantly. On the other hand, patients with lymphadenopathy had significantly higher scores $(p=0.033)$, as summarized in Table 2.

\section{Discussion}

The breast is a seen now as a complex organ, both anatomically and physiologically (i.e. several beast phenotypes are now recognized with variable parynchymal complexities) [12]. Mainly composed of a fatty tissue stroma in which the parenchymal mammary gland is embedded [13], the breast undergoes several episodic and periodic changes related to menarche, menstruation, pregnancy, lactation, menopause, and beyond [14]. All these changes, in addition to genetic and nutritional factors, affect the breast size and the probability of breast disease [15]. The current study showed a statistically significant positive correlation between the BI-RADS score (i.e. risk of malignancy) with breast size, age, postmenopausal state, and personal or familial history of breast disease. To the best of our
Table 2: Effects of anatomical and physiological factors on BI-RADS scores in Iraqi women presenting with a breast lump

\begin{tabular}{|c|c|c|c|c|c|}
\hline \multirow[t]{3}{*}{ Affecting criteria } & \multicolumn{4}{|c|}{ BI-RADS score } & \multirow[t]{3}{*}{$\mathrm{p}$-value } \\
\hline & 2 & 3 & 4 & 5 & \\
\hline & \multicolumn{4}{|l|}{$\%$} & \\
\hline \multicolumn{6}{|l|}{ Menopausal state } \\
\hline Premenopausal & 96.4 & 69.2 & 60 & 44.4 & \multirow[t]{2}{*}{0.004} \\
\hline Postmenopausal & 3.6 & 30.8 & 40 & 55.6 & \\
\hline \multicolumn{6}{|c|}{ Personal history of breast disease } \\
\hline Yes & 7.1 & 30.8 & 70 & 22.2 & \multirow[t]{2}{*}{0.001} \\
\hline No & 92.9 & 69.2 & 30 & 77.8 & \\
\hline \multicolumn{6}{|c|}{ Family history of breast disease } \\
\hline Yes & 42.9 & 53.8 & 80 & 55.5 & \multirow[t]{2}{*}{0.013} \\
\hline No & 57.1 & 46.2 & 20 & 44.4 & \\
\hline \multicolumn{6}{|l|}{ Marital status } \\
\hline Married & 78.6 & 100 & 80 & 100 & \multirow[t]{2}{*}{0.147} \\
\hline Single & 21.4 & 0 & 20 & 0 & \\
\hline \multicolumn{6}{|c|}{ Parity (in married women) } \\
\hline Multiparous & 81.8 & 84.6 & 100 & 88.9 & \multirow[t]{3}{*}{0.384} \\
\hline Nulliparous & 4.5 & 15.4 & 0 & 11.1 & \\
\hline Uniparous & 13.6 & 0 & 0 & 0 & \\
\hline \multicolumn{6}{|c|}{ Breast feeding (in parous women) } \\
\hline Yes & 86.4 & 69.2 & 100 & 88.9 & \multirow[t]{2}{*}{0.262} \\
\hline No & 13.6 & 30.8 & 0 & 11.1 & \\
\hline \multicolumn{6}{|l|}{ Lymphadenopathy } \\
\hline Yes & 25 & 46.2 & 70 & 66.7 & \multirow[t]{2}{*}{0.033} \\
\hline No & 75 & 53.8 & 30 & 33.3 & \\
\hline \multicolumn{6}{|c|}{ Involved breast quadrant } \\
\hline Upper lateral & 50 & 46.2 & 30 & 22.2 & \multirow[t]{4}{*}{0.414} \\
\hline Lower lateral & 35.7 & 38.5 & 40 & 22.2 & \\
\hline Lower medial & 10.7 & 7.7 & 10 & 22.2 & \\
\hline Upper medial & 3.6 & 7.7 & 20 & 33.3 & \\
\hline
\end{tabular}

knowledge, no previous study used anthropometric breast size as a risk factor for the development of high BI-RADS scores or risk of breast malignancy. The effect of breast size on such risk may be related to several factors. Firstly, large breast size may be part of an overall state of overweight or obesity, yet, the this study does not include obesity in the study parameters, previous evidence shows the increased risk of malignant breast disease with it [16]. Secondly, larger breasts are more prone to mechanical trauma (Lu et al. suggested that Breast displacement of a female body during exercise might cause discomfort, breast pain, and even other injury to breast tissue) [17], especially in relation to wearing ill-fitted or unsuitable bras [18]. Finally, it may pose a certain degree of difficulty for patients to perform and/or detect breast lumps in larger breasts during self-examination, leading to a presentation of a higher BI-RADS score in larger breasts [19]. While the affected breast quadrant did not have an effect of the BI-RADS score outcome, the upper lateral quadrant of the breast remained the most affected region regardless of the score. This is consistent with other studies and may be related to the greater anatomical abundancy of parenchymal breast tissue in that quadrant [20], [21]. Age and postmenopausal state play a double role in increasing the BI-RADS score in the study. Several local and international studies may differ in the age group most susceptible to breast malignancy, but they almost invariably agree that the risk increases with increasing age [22]. This may be related to the longer exposure to dietary and other environmental factors that increase the risk [23]. The paramenopausal risk increase may be related to postmenopausal hormonal therapy use [24], premenopausal use of oral contraceptives [25], the timing of menarch/menopause [26] or a combination of all. Personal and familial history of breast cancer 
increases the risk of high BI-RADS scores mainly by the inclusion of genetic risk factors and to lesser degree an increasing chance of gene mutation [27], [28]. Whereas many studies show a protective effect of marriage, parity and breastfeeding against breast cancer [29], the fact that the current study showed none may be related to discrepancies in these factors initiation and duration or simply a difference in sample size, ethnicity, and social standards [30].

\section{Conclusion}

Ultrasonic BI-RADS scoring of breast lumps provides an initial reliable tool for the management of breast disease. Higher scores are associated with increasing breast size, age, postmenopausal state and personal or familial history of breast disease. Several anatomical, physiological, hereditary, and environmental aspects influence such factors.

\section{References}

1. Bray F, Ferlay J, Soerjomataram I, Siegel RL, Torre LA, Jemal A. Global Cancer Statistics 2018: GLOBOCAN estimates of incidence and mortality worldwide for 36 cancers in 185 countries. CA Cancer J Clin. 2018;68(6):394-424. https://doi. org/10.3322/caac.21492

PMid:30207593

2. Kelly KM, Dean J, Comulada WS, Lee SJ. Breast cancer detection using automated whole breast ultrasound and mammography in radiographically dense breasts. Eur Radiol. 2010;20(3):734-42. https://doi.org/10.1007\%2Fs00330-009-1588-y

PMid:19727744

3. Smith RA, Cokkindes V, Brooks D, Saslow D, Shah M, Brawley OW. Cancer screening in the United States, 2011: A review of current American cancer society guidelines and issues in cancer screening. CA Cancer J Clin. 2011;61(1):8-30. https://doi.org/10.3322/caac.20096

PMid:21205832

4. Alwan NA. Tumor characteristics of female breast cancer: Pathological review of mastectomy specimens belonging to Iraqi patients. World J Breast Cancer Res. 2018;1(1):1006.

5. Alwan NA. Breast Cancer among Iraqi women: Preliminary findings from a regional comparative breast cancer research project. J Glob Oncol. 2016;2(5):255-8. https://doi.org/10.1200/ jgo.2015.003087

PMid:28717711

6. Alwan NA, Tawfeeq F, Maallah M, Sattar S. The stage of breast cancer at the time of diagnosis: Correlation with the clinicopathological findings among Iraqi patients. J Neoplasm 2017;2:1-10. http://doi.org/10.21767/2576-3903.100020

7. AbdulWahid HM, Khalel EA, Alwan NA. Mammographic, ultrasonographic and pathologic correlations of focal asymmetric breast densities among a sample of Iraqi women. J Contemp Med Sci. 2019;5(3):131-5. https://doi.org/10.22317/ jcms.v5i3.602
8. Goyal SK, Choudhary D, Beniwal S, Kapoor P, Goyal PK. Retrospective analysis of breast lumps in a given population: An institutional study. Int Surg J. 2016;3(3):1547-50. https://doi. org/10.18203/2349-2902.isj20162745

9. Elkharbotly A, Farouk HM. Ultrasound elastography improves differentiation between benign and malignant breast lumps using B-mode ultrasound and color Doppler. Egypt J Radiol Nuclear Med. 2015;46(4):1231-9. https://doi.org/10.1016/j. ejrnm.2015.06.005

10. Kayar R, Civelek S, Cobanoglu M, Gungor O, Catal H, Emiroglu M. Five methods of breast volume measurement: A comparative study of measurements of specimen volume in 30 mastectomy cases. Breast Cancer. 2011;5:43-52. https://doi. org/10.4137/bcbcr.s6128

PMid:21494401

11. Spak DA, Plaxco JS, Santiago L, Dryden MJ, Dogan BE. BI-RADS ${ }^{8}$ fifth edition: A summary of changes. Diagn Interv Imaging. 2017;98(3):179-90. https://doi.org/10.1016/j. diii.2017.01.001

PMid:28131457

12. Kontos D, Winham SJ, Oustimov A, Pantalone L, Hsieh MK Gastounioti A, et al. Radiomic phenotypes of mammographic parenchymal complexity: Toward augmenting breast density in breast cancer risk assessment. Radiology. 2018;290(1):41-9. https://doi.org/10.1148/radiol.2018180179 PMid:30375931

13. Bland KI, Copeland EM, Klimberg VS, Gradishar WJ. The Breast: Comprehensive Management of Benign and Malignant Diseases. Netherlands: Elsevier Inc.; 2017. https://doi. org/10.1016/C2014-0-01946-6

14. Shah R, Alhawaj AF. Physiology, breast milk. In: StatPearls Treasure Island, FL: StatPearls Publishing; 2020.

15. Kurian AW, Griffith KA, Hamilton AS, Ward KC, Morrow M, Katz SJ, et al. Genetic testing and counseling among patients with newly diagnosed breast cancer. JAMA. 2017;317(5):531-4. https://doi.org/10.1001/jama.2016.16918 PMid:28170472

16. Picon-Ruiz M, Morata-Tarifa C, Valle-Goffin JJ, Friedman ER, Slingerland JM. Obesity and adverse breast cancer risk and outcome: Mechanistic insights and strategies for intervention. CA Cancer J Clin. 2017;67(5):378-97. https://doi.org/10.3322/ caac. 21405 PMid:28763097

17. Li X, Guo X. Progressive fat necrosis after breast augmentation with autologous lipotransfer: A cause of long-lasting high Fever and axillary lymph node enlargement. Aesthetic Plast Surg. 2015;39(3):386-90. https://doi.org/10.1007/s00266-015-0480-1 PMid:25846899

18. Lu M, Qu J, Wang G, Dai X. Mechanical analysis of breast-bra interaction for sports bra design. Mater Today Commun. 2016;6:28-36. https://doi.org/10.1016\%2Fj. mtcomm.2015.11.005

19. Siddharth R, Gupta D, Narang R, Singh P. Knowledge, attitude and practice about breast cancer and breast self-examination among women seeking out-patient care in a teaching hospital in central India. Indian J Cancer. 2016;53(2):226. https://doi. org/10.4103/0019-509x.197710

PMid:28071615

20. Nahar N, Iqbal M, Rahman KM, Arif NU, Rahman MM, Naheen T, et al. Rate of distribution of breast lump in different quadrants with their cytological findings in both sex. J Natl Inst Neurosci Bangladesh. 2019;5(1):69-71. https://doi.org/10.3329/jninb. v5i1.42173

21. Lee $\mathrm{AH}$. Why is carcinoma of the breast more frequent in the upper outer quadrant? A case series based on needle core biopsy diagnoses. Breast. 2005;14(2):151-2. https://doi. 
org/10.1016/j.breast.2004.07.002

PMid:15767185

22. Alwan NA, Kerr D,Al-Okati D, Pezella F, Tawfeeq FN. Comparative study on the clinicopathological profiles of breast cancer among Iraqi and British patients. Open Public Health J. 2018;11(1):17791. https://doi.org/10.2174/1874944501811010177

23. Van Maele-Fabry G, Lombaert N, Lison D. Dietary exposure to cadmium and risk of breast cancer in postmenopausal women: Asystematic review and meta-analysis. Environ Int. 2016;86:1-3. https://doi.org/10.1016/j.envint.2015.10.003 PMid:26479829

24. Kotsopoulos J, Huzarski T, Gronwald J, Moller P, Lynch HT, Neuhausen SL, et al. Hormone replacement therapy after menopause and risk of breast cancer in BRCA1 mutation carriers: Acase-controlstudy.BreastCancerResTreat.2016;155(2):365-73. https://doi.org/10.1007/s10549-016-3685-3

PMid:26780555

25. Brinton LA, Brogan DR, Coates RJ, Swanson CA, Potischman N, Stanford JL. Breast cancer risk among women under 55 years of age by joint effects of usage of oral contraceptives and hormone replacement therapy. Menopause. 2018;25(11):1195200. https://doi.org/10.1097/GME.0000000000001217

PMid:30358713
26. Collaborative Group on Hormonal Factors in Breast Cancer Type and timing of menopausal hormone therapy and breast cancer risk: Individual participant meta-analysis of the worldwide epidemiological evidence. Lancet. 2019;394(10204):1159-68. https://doi.org/10.1016/S0140-6736(19)31709-X

27. Shiovitz S, Korde LA. Genetics of breast cancer: A topic in evolution. Ann Oncol. 2015;26(7):1291-9. https://doi. org/10.1093\%2Fannonc\%2Fmdv022

PMid:25605744

28. Hameed AF, Ibraheem MM, Ahmed BS. C-MYC and BCL2 expression in normal tissue around proliferative breast conditions in relation to ER, PR in a sample of Iraqi women. UK J Pharm Biosci. 2018;6(3):1-6. https://doi.org/10.20510/ukjpb/6/ i3/173544

29. Noel KI, Ahmed ZO, Khamees NH. Comparison of biparietal diameter (BPD) and estimated fetal weight (EFW) in single and multiple pregnancies during third trimester of gestation in a sample of Iraqi women. Biochem Cell Arch. 2020;2:4549-54.

30. Unar-Munguía M, Torres-Mejía G, Colchero MA, Gonzalez de Cosio T. Breastfeeding mode and risk of breast cancer: A doseresponse meta-analysis. J Hum Lactation. 2017;33(2):422-34. https://doi.org/10.1177/0890334416683676

PMid:28196329 